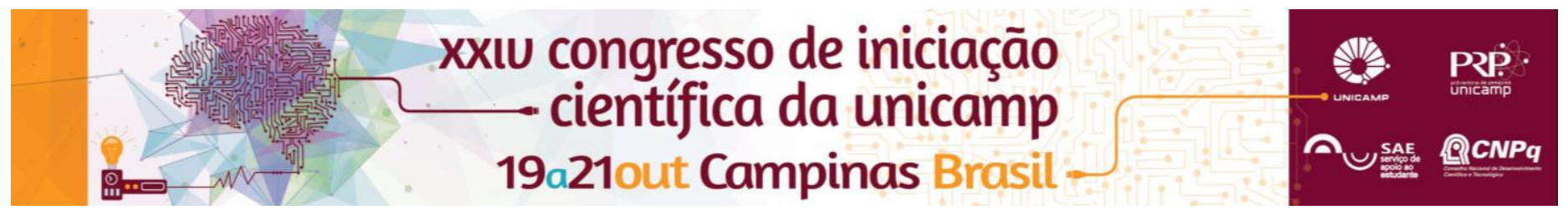

\title{
Alteridade e personalidade: interlocuções entre a persona performática de Cohen e o papel do outro de Wallon
}

\section{Camila Estela Cassis Freitas}

\begin{abstract}
Resumo
A partir da leitura das obras de Henri Wallon (França, 1879-1962) e Renato Cohen (Brasil, 1956- 2003), psicólogo da educação e teórico do teatro, respectivamente, notamos uma potencial interlocução entre eles no que concerne à construção da personalidade da pessoa, bem como o papel da alteridade neste processo e o caráter performático da alteridade. No presente projeto, colocamos Wallon e Cohen frente a frente, explorando a frutífera interação entre Psicologia, Educação e Teatro. Assim, pretendemos responder a questões que abrangem a formação e consciência do "eu", a inserção desse "eu" no meio social e a maior compreensão do estatuto do homem, entendendo o homem como persona performática. Esse estudo se insere, assim, no âmbito das pesquisas que vem sendo realizadas por integrantes do Grupo de Pesquisa Pensamento e Linguagem (FE, Unicamp), sobre a formação da personalidade e o $\begin{array}{lllll}\text { estatuto da } & \text { da } & \text { arte } & \text { desenvolvimento humano. }\end{array}$
\end{abstract}

\section{Palavras-chave}

Educação, Sociogênese, Teatro

\section{Introdução}

A partir da leitura das obras "As origens do caráter na criança" e "O papel do outro", de Henri Wallon (18791962), psicólogo, filósofo e médico francês, pudemos relacionar as teorias que ele elabora sobre a importância do outro social - a alteridade - no desenvolvimento da personalidade do ser humano e na constituição da consciência de si/do mundo com as teorias do performer e teórico teatral brasileiro, autor de "Performance como linguagem", Renato Cohen (1956-2003), a respeito do caráter performático da alteridade, ou seja, do estatuto metodológico-artístico do aprendizado da alteridade. Com essa pesquisa, buscamos mostrar como as experiências e teorias em Artes podem contribuir para os estudos na área de Educação, bem como explorar como o estudo do ser humano a partir das teorias antropológico-teatrais trazem uma nova abordagem à questão do Estatuto do Homem.

\section{Resultados e Discussão}

Assumindo o princípio da sociogênese, isto é, da natureza social do desenvolvimento humano, Wallon argumenta sobre a emergência da consciência pela elaboração de uma teoria das emoções. O corpo vibrante e indefeso do bebê afeta o outro, convocando e produzindo re-ações nesse outro. O corpo é, assim, o substrato primeiro da individualidade, sendo que o estado inicial da consciência implica sujeito e realidade exterior em uma con-fusão primitiva. A diferenciação, isto é, a distinção entre 0 eu e 0 outro só se adquire progressivamente, num processo que se faz nas e pelas interações sociais, de modo que o sentido do processo de socialização é de crescente individuação. Para Wallon, a alteridade e a afetividade constroem ativamente a personalidade (expressa pelo caráter, formada por opiniões, representações, imagens e técnicas aprendidas, bem como pelas emoções e suas ressonâncias afetivas). O desenvolvimento das sensibilidades orgânicas e da noção do próprio corpo, que não são dadas a priori, possibilita a elaboração da consciência de si como pessoa, como sujeito individual, em movimento solidário à consciência do outro, do alter, da alteridade. Nesse sentido, as teorias de Renato Cohen sobre a atuação performática no desenvolvimento das formas de relacionamento entre as pessoas e seu conceito de persona performática aproximam-se profundamente das teorias de Wallon. O método teatral de Cohen da persona performática sugere a vivência das ações através da incorporação da alteridade, constituindo, dentro da interlocução que desenvolvemos, uma experiência metodológica, na arte cênica, da alteridade, afetividade e personalidade explicadas por Wallon.

\section{Conclusões}

Nesta pesquisa de caráter teórico pudemos explorar o papel da alteridade na formação da personalidade da criança, bem como o caráter performático da mesma, tendo como norteadoras as indagações: como a dinâmica social impacta, afeta e/ou constitui a personalidade do sujeito e a do personagem? Como conceber sensibilidade e alteridade nesses processos? Como o desenvolvimento da pessoa é permeado por e se relaciona com o desenvolvimento da arte? Os trabalhos de Wallon com as ideias de personalidade, alteridade, afetividade e fusão - transpassando conceitos próprios como a de diferenciação, imitação, sociabilidade, consciência - instigaram as interlocuções com as ideias de Renato Cohen, idealizador do caráter performático da alteridade. No trabalho e na arte teatral deste último, que explora também as ideias de identidade, alteridade, afetividade e fusão transpassando seus conceitos originais de travessia, persona performática, desenvolvimento da linguagem, mitologia pessoal e estranhamento -, encontramos fecundas aproximações com o campo conceitual walloniano. No exercício analítico de textos destes dois autores, contribuímos para um adensamento teóricoconceitual nos campos da psicologia do desenvolvimento e do teatro.

WALLON, Henri. Origens do cárater na criança. Manole, São Paulo, 1989. COHEN, Renato. Performance como linguagem. São Paulo: Editora Perspectiva, 